\section{SBR}

\section{SMALL BUSINESS} INTERNATIONAL REVIEW
JOURNAL: Small Business International Review ISSN: 2531-0046

SECTION: Research Articles

VOLUME: 4; ISSUE: 1; PAGES: 16-33

DOI: https://doi.org/10.26784/sbir.v4i1.243

SUBMITTED: $2019-07-28$

ACCEPTED: 2019-09-18

PUBLISHED: 2020-01-01

\title{
Corporate Social Responsibility (CSR) by small and medium enterprises (SMEs): a systematic review
}

\section{Responsabilidad Social Corporativa (RSC) en las pequeñas y medianas empresas (PYMEs): una revisión sistemática}

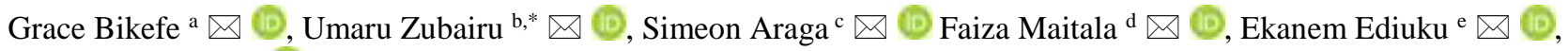 \\ Daniel Anyebe ${ }^{\mathrm{f}} \triangle(\mathrm{B}$ \\ $a, d$, e) Nile University of Nigeria (Nigeria) \\ $b, c, f)$ Federal University of Technology Minna (Nigeria) \\ * Corresponding author: uzubairu@gmail.com (Umaru Zubairu)
}

\section{Abstract}

This study aims to systematically review the key characteristics and issues in Corporate Social Responsibility among Small and Medium Enterprises (CSRS) research. The Systematic Assessment Quantitative Technique (SQAT) developed by Australian researchers, Catherine Pickering and Jason Antony Byrne, was used to identify and analyse 62 peer-reviewed CSRS articles from six high quality academic databases. Most of the studies took place in Europe and Asia while South America has been largely ignored. A significant number of CSRS research were empirical in nature, meaning that there is a need for more conceptual studies to aid the understanding of new CSRS norms and underlying factors. Additionally, CSRS articles focused mainly on identifying the various ways SMEs are implementing CSR. Finally, most CSRS articles adopted a single research method, with survey being the most dominant method. There is a need for future studies to combine a variety of methods so as to gain additional insight into CSRS related issues

Keywords: Corporate Social Responsibility; SMEs; systematic review

JEL Classification: M14; M15

\section{Resumen}

Este estudio tiene como objetivo revisar sistemáticamente las características y los problemas claves en la investigación de la Responsabilidad Social Corporativa en las Pequeñas y Medianas Empresas (RSC). Empleando la técnica cuantitativa de evaluación sistemática (SQAT), desarrollada por los investigadores australianos, Catherine Pickering y Jason Antony Byrne, se identificaron y analizaron 62 artículos revisados por pares de seis bases de datos académicas de alta calidad. La mayoría de los trabajos se realizaron en Europa y Asia, mientras que América del Sur ha quedado ignorada en gran medida. Un número significativo de investigaciones fueron de naturaleza empírica, lo que significa que existe una necesidad de más estudios conceptuales para ayudar a comprender las nuevas normas y los factores subyacentes sobre RSC. Además, los artículos de RSC se centraron principalmente en identificar las diversas formas en que las PYME están implementando la RSC. Finalmente, la mayoría de los artículos adoptaron un único método de investigación, siendo la encuesta el método más dominante. Es necesario que los estudios futuros combinen una variedad de métodos para obtener información adicional sobre los problemas relacionados con la RSC

Palabras clave: Responsabilidad Social Corporativa; PYMEs; revisión sistemática

Clasificación JEL: M14; M15 


\section{Introduction}

In CSR discourse, there is often a misconception that CSR activities are only carried out by large and highly profitable businesses (Jansson et al., 2017; Meyer et al., 2017; Lucky, 2018). However, the reality is that Small and Medium Enterprises (SMEs) also have a great role to play in the global CSR landscape (Jansson et al., 2017; López-Pérez et al., 2017; Waithe, 2018). The case of Wecyclers, a waste-management SME in Nigeria, provides evidence of this notion. As part of its CSR activities, Wecyclers offers waste collection service to some residents at no cost (The Tony Elemelu Foundation, 2017; Sustainia, 2018). This Wecyclers' CSR activity has contributed to improved waste management in the region, while the SME has also gained international recognition because of its CSR efforts (Akinpelu, 2019; Annor, 2019; Oluwole, 2019). For instance, to encourage further implementation of the SME's CSR activities two international foundations, the King Baudoin Foundation and the Case Foundation awarded 200,000 Euros and 50,000 dollars, respectively to Wecyclers (Akinpelu, 2019; Annor, 2019; Oluwole, 2019).

CSR is a channel through which businesses, including SMEs contribute to societal goals (Meyer et al., 2017; Schmidt et al., 2018; Yeo \& Carter, 2018). CSR implementation is useful for businesses to mitigate the negative effects their operations may have on the environment, as businesses contribute to the depletion of the environment (Jamali et al., 2017; Doshmanli et al., 2018; Melissen et al., 2018). CSR is implemented through ideal labour, production and environmental practices, and also through good community relations (Van Woerkom \& ZeijlRozema, 2017; Mazoor et al., 2019; Sharma \& Gupta, 2019). For instance, Beltij Limited donated boreholes and learning materials to a school in the community it carries out its operations (The Guardian, 2018).

Implementation of CSR may be voluntary or a legal requirement (Amor-Esteban et al., 2018; Dubruc et al., 2018; Col \& Patel, 2019). To ensure CSR is beneficial to both businesses and the society, it is important that its implementation is in line with the company's business strategy (Maas \& Boons, 2017; Moneva \& Hernández-Pajares, 2018; Kucharska \& Kowalczyk, 2019).

A majority of CSR research has focused on CSR by large companies, with relatively little attention given to CSR activities done by SMEs (Panwar et al., 2017; Dubruc et al., 2018; Lucky, 2018). This is despite the fact that SMEs account for about 95 percent of businesses globally, and in most countries they contribute more than half of the employment and GDP (Organization for Economic Cooperation and Development [OECD], 2017; United Nations, 2019; World Bank, 2019). The neglect has been linked to their size, as it is assumed that because of their size their impact on the business environment is minimal (Panwar et al., 2017; Edgell, 2018; Al-Tit et al., 2019). Although individually their impact may be minimal, their collective CSR impact is huge (OECD, 2017; Edgell, 2018; Takalendze \& Mohammed, 2019). SMEs are fundamental to the efforts to achieve global sustainable development (López-Pérez et al., 2017; Wu, 2017; United Nations, 2019). Sustainable development is when the environment is not compromised in the process of meeting current economic needs (Carley \& Christie, 2017; López-Pérez et al.,2017; Stafford-Smith et al., 2017). Therefore, it is important that researchers, regulators and other stakeholders pay more attention to the implementation of CSR in SMEs.

This study aims to address this research gap by conducting a systematic review of CSR research in an SME (CSRS) context. Papers in this review were sourced from six databases; Emerald, Elsevier, Sage, Springer, Taylor \& Francis and Wiley. These databases were chosen because they are known to publish a large percentage of peer reviewed papers. It is believed that peer reviewed papers are of high quality, because a lot of rigor is involved in reviewing them (Sidalak et al., 2017; Caputo, 2019).

This study is time bound as it uses articles published between 2010 and 2019, and the choice of this timeline is because the research aims to focus on recent developments in the area. The world is dynamic, and as a result new norms and underlying factors that concern this area are 
occurring. In the past, CSR involved mere philanthropy (Maas \& Boons, 2017; Jamali \& Karam, 2018; Melissen et al., 2018), however, in recent years, several issues have emerged that concern CSR, for instance, socially responsible human resources management, green practices are all considered integral parts of CSR (Rothenberg et al., 2017; McClimon, 2019; Sharma \& Gupta, 2019).

To achieve the aim of the study, important characteristics of CSRS were identified. This was done by analysing the downloaded papers based on the following factors: time distribution, geographic distribution, the type of article (conceptual vs. empirical), theories, themes and methods used in the papers. The analyses done will identify research gaps in this area, which will provide a direction for future research for both old and intending researchers of this area. From a managerial perspective, the gaps identified will highlight issues in this area that require immediate attention.

The rest of the paper is structured as follows: The next section on literature review discusses prior systematic reviews on CSRS. This review differs from prior reviews because it is comprehensive and covers a more recent timeline. This is followed by a methodology section, which discusses the method and processes used in conducting this study. The subsequent section discusses the findings of this study, and also highlights directions for future research based on these findings. Finally, a section which discusses the limitations of the study, and makes suggestions based on the identified limitations concludes the paper.

\section{Literature review}

An examination of CSRS literature revealed that two systematic reviews have been published in the six databases utilized for this review between 2010-2019 (Vázquez-Carrasco \& LópezPérez, 2012; Ortiz-Avram et al., 2018). Vázquez-Carrasco and López-Pérez (2012) did a comprehensive review of CSRS research, while Ortiz-Avram et al. (2018) focused on a specific aspect of CSRS. Both studies will be discussed in the succeeding paragraphs.

Vázquez-Carrasco \& López-Pérez (2012) in conducting a systematic review of CSRS research, utilized 28 English peer reviewed articles sourced from selected management and SME journals. This study was not time bound. However, the earliest article featured in this systematic review was published in 2006, while the latest was published in 2011. According to the author, the oldest reference to CSRS research was in 2006 (Vázquez-Carrasco \& LópezPérez, 2012). The latest publication year of articles featured in the study was 2011, this is because the study was published in 2012. The systematic review focused on the identification of themes and methodologies adopted in CSRS research.

Ortiz-Avram et al. (2018) conducted a systematic review of CSRS research, which focused on the integration of CSR into the strategies of SMEs. 118 peer reviewed English articles obtained from two databases (Web of Science and Scopus) were reviewed. This study was time bound as articles published between 1997 to 2016 were utilized. The articles were reviewed based on time and geographical distribution, and methodology adopted. Also, content analysis was used to explore the different terms used to characterize CSR in the context of SME strategy.

To the best of the researcher's knowledge there is limited evidence of systematic reviews of published CSRS articles. This is evidenced by the fact that only two prior systematic reviews were identified by the researcher. The limited number of systematic reviews may be because, CSRS research only became prevalent in recent years (Vázquez-Carrasco \& López-Pérez, 2012).

Analyses of prior systematic reviews revealed that the most recent study (Ortiz-Avram et al., 2018) focused on one specific aspect of CSRS research. This current study conducts a comprehensive review of CSRS research, and its findings are very important considering that SMEs are fundamental to the efforts to achieve global sustainable development. The following section outlines the methodology adopted in this study. 


\section{Methodology}

In conducting this systematic review of CSRS research, this study adopted the "systematic quantitative assessment technique" (SQAT) developed by Pickering and Byrne (2013). SQAT facilitates the production of reproducible and verifiable reviews, through the identification of "important geographic, scalar, theoretical and methodological gaps in the literature" (Pickering \& Byrne, 2013, p. 11).

SQAT recommends five important steps in conducting an effective systematic review. Each step and how it was applied in this study is described in Table 1. A total of sixty two peerreviewed English CSRS articles met the selection criteria from six databases. Table 2 presents the number of articles downloaded from each database utilized.

Table 1. Description and application of SQAT

\begin{tabular}{|c|c|c|}
\hline & Step & Application in current study \\
\hline 1. & Define topic & Corporate Social Responsibility in Small and Medium Enterprises \\
\hline 2. & $\begin{array}{l}\text { Formulate } \\
\text { research } \\
\text { questions }\end{array}$ & $\begin{array}{l}\text { Six research questions: } \\
\text { 1. What is the time distribution of CSRS research articles? } \\
\text { 2. In which countries were these articles written? } \\
\text { 3. What kind of CSRS articles were published? (Conceptual vs. Empirical) } \\
\text { 4. What kind of theories were applied in these articles? } \\
\text { 5. What are the specific themes these articles explored, and what were the } \\
\text { major findings in each theme? } \\
\text { 6. What research methods were utilized to conduct the research? }\end{array}$ \\
\hline 3. & $\begin{array}{l}\text { Identify key } \\
\text { words }\end{array}$ & "Corporate Social Responsibility", "Small and Medium Enterprises" \\
\hline 4. & $\begin{array}{l}\text { Identify } \\
\text { and search } \\
\text { databases }\end{array}$ & $\begin{array}{l}\text { 1. } 6 \text { databases utilized: Elsevier; Emerald, Sage, Springer; Taylor and Francis; } \\
\text { Wiley } \\
\text { 2. "All in title" search using three search combinations: } \\
\text { a. "Corporate Social Responsibility" + "Small and Medium Enterprise" } \\
\text { b. "CSR" + "SME" } \\
\text { c. "Corporate Social Responsibility" + "SME" }\end{array}$ \\
\hline 5. & $\begin{array}{l}\text { Read and assess } \\
\text { publications }\end{array}$ & $\begin{array}{l}\text { 1. Abstracts of papers found were read to ensure that they were dealing with } \\
\text { Corporate Social Responsibility in Small and Medium Enterprises. } \\
\text { 2. Literature reviews, book chapters and conference proceedings were not } \\
\text { included; only peer-reviewed conceptual and empirical papers. }\end{array}$ \\
\hline \multicolumn{3}{|c|}{ Source: Authors } \\
\hline
\end{tabular}

Table 2. Number of Papers downloaded in databases

\begin{tabular}{|c|c|c|}
\hline & Database & Number of Papers \\
\hline 1 & Emerald & 21 \\
\hline 2 & Elsevier & 9 \\
\hline 3 & Sage & 7 \\
\hline 4 & Springer & 8 \\
\hline 5 & Taylor \& Francis & 7 \\
\hline \multirow[t]{2}{*}{6} & Wiley & 10 \\
\hline & Total & 62 \\
\hline
\end{tabular}

Source: Authors 


\section{Findings, discussions and suggestions for future research}

\subsection{Time Distribution of Articles on CSR in SMEs Context}

Based on this study's sample of 62 articles, published between 2010-2019, a time distribution analysis of CSRS research was done. This analysis revealed that a peak was reached in 2016 and 2017 (11 articles respectively). The minimum number of articles was published in 2015 being two articles. Articles were published every year between the timeline of 2010-2019. So far, only three articles have been published in 2019. However, it is important to note that papers used for this analysis were downloaded on $23^{\text {rd }}$ June, 2019. It is expected that more articles will be published by the end of 2019 (Figure 1).

\section{Figure 1: Time Distribution of Articles on CSR in SMEs}

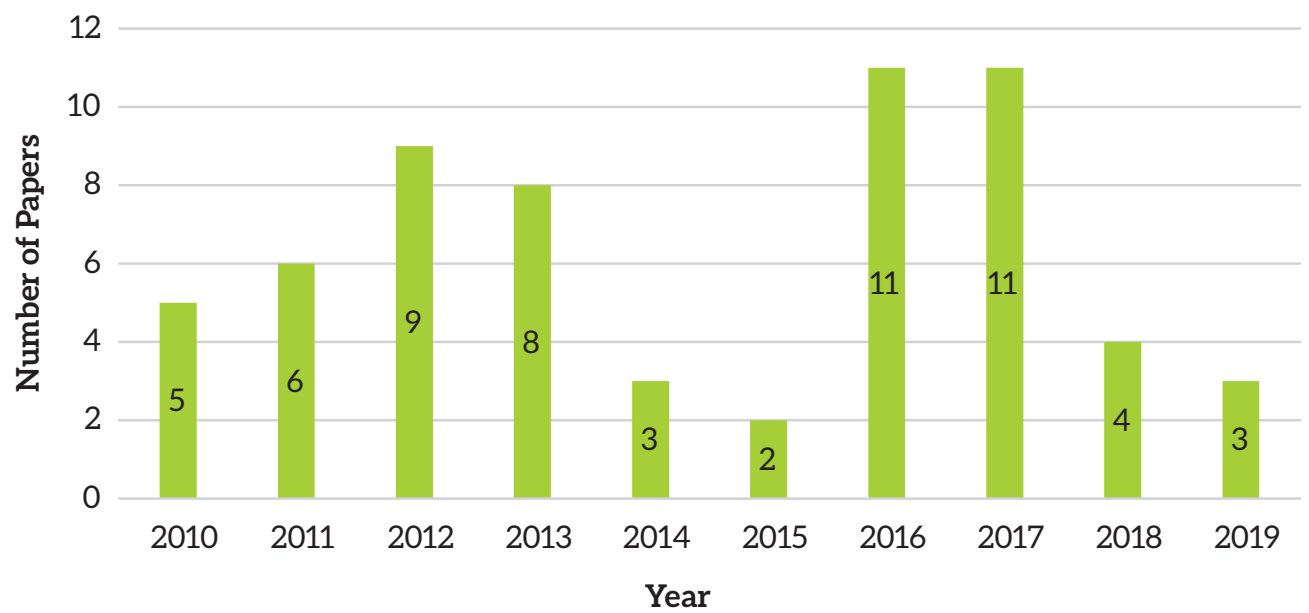

Source: Authors' review

\subsection{Geographical Distribution of Articles on CSRS}

Figure 2 presents the geographical distribution of the 62 CSRS articles reviewed in this study.

Figure 2 Geographical Distribution of Articles on CSR in SMEs from 2010-2019.

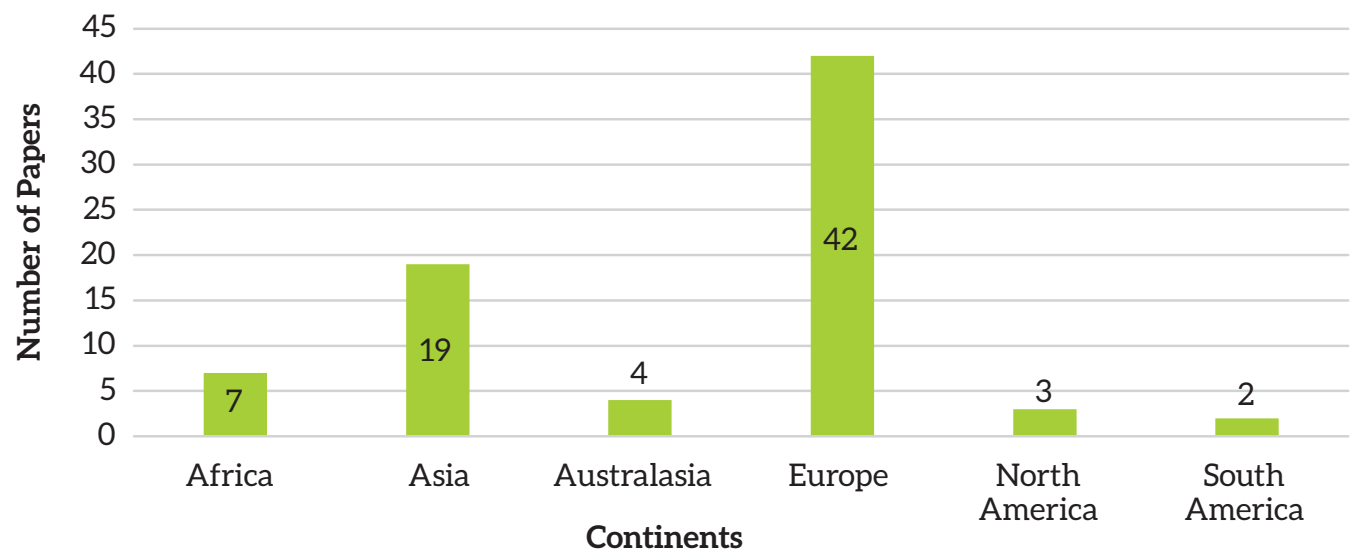

Source: Authors' review 
The analysis showed that Europe has the highest number of articles published (42), followed by Asia (19), Africa (7), Australasia (4), North America (3), and finally South America (2). South America had the least number of studies in this area, and this reflects a geographical gap in CSRS research. South America has been described as one of the continents with high poverty levels, and Ray (2018) stated that 61 million people live in extreme poverty in the continent. Although the individual impact of CSR implementation in an SME may be small, their collective impact is huge (OECD, 2017; Edgell, 2018). Therefore, the implementation of CSR by SMEs in South America is likely to improve the continent's economic and environmental conditions. Conducting CSRS research in South America will help identify how best CSR implementation by SMEs can contribute to the continent's economic sustainability. Hence, future researchers should address this geographical research gap.

From a country perspective, 34 countries were represented in the systematic review of CSRS research. Figure 3 presents the top four countries where CSRS research was conducted. The analysis shows that Spain is the country with the highest number of articles (9), followed by India (6), then China and Italy (both countries have 5 articles each). All top four countries belong to the European and Asian continents, and both continents have the highest numbers of CSRS research (Figure 3).

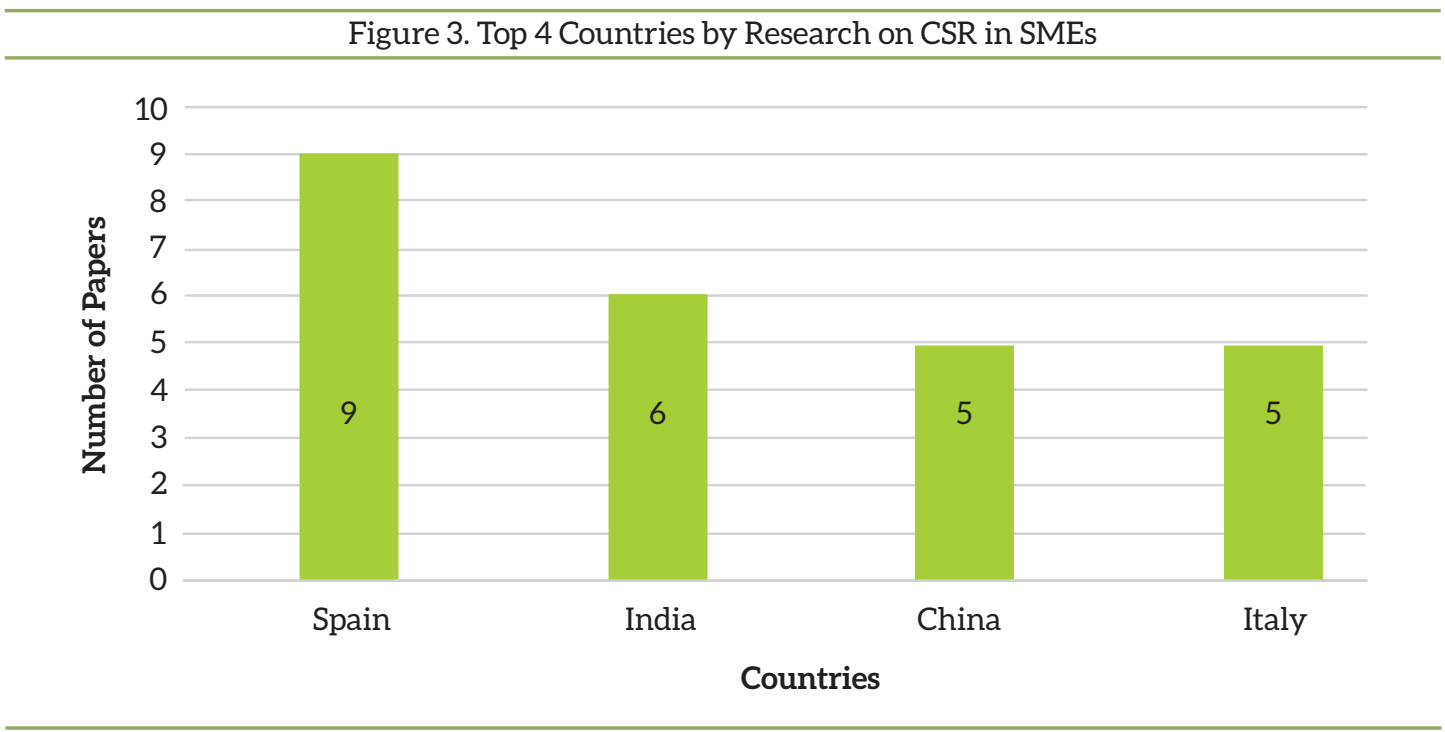

Source: Authors' review

Country analysis showed that 34 countries had published CSRS research; this number is low when compared with the total number of countries in the world. According to worldatlas. com, there are currently 196 countries in the world, including Taiwan (World Map, 2019). A limitation of this study is its inclusion of only articles published in English. Nonetheless, many countries are not represented in CSRS research. SMEs are fundamental to the efforts to achieve global sustainable development (United Nations, 2019). Hence, it is important that researchers in all countries conduct CSRS research. This will identify the level of contribution being made by SMEs, how positive contributions can be made by SMEs through CSR and how to mitigate any negative effect of SMEs operations on the society, amongst other issues.

\subsection{Article Type}

The 62 articles used in the systematic review were divided into two categories: conceptual and empirical. Conceptual articles are those that offer theoretical discussions on the subject, while empirical articles are those which involve data collection in order to test a particular hypothesis in the real world (Patten \& Newhart, 2017). Figure 4 shows the breakdown of the 62 CSRS articles based on the above classification. 


\section{Figure 4: Article Type Breakdown}

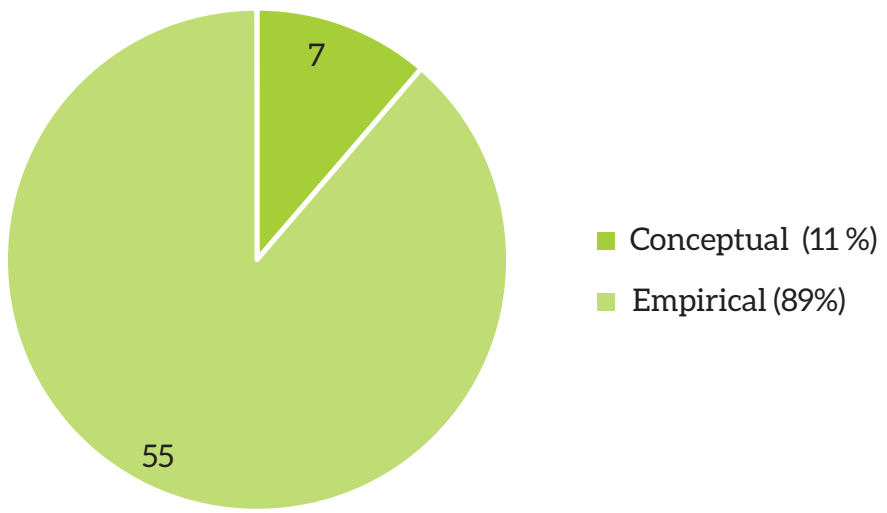

Source: Authors' review

A significant majority of the papers reviewed were empirical in nature (89\%, 55 out of 62$)$. Empirical research is important as it validates existing theories and concepts. However, because of the limited number of conceptual CSRS articles in this review, more conceptual research needs to be done as this contributes to a better understanding of emerging norms and factors. Additionally, conceptual research will also provide direction and impetus for future empirical research enquiry into CSRS.

\subsection{Theory Breakdown of CSRS Research}

Figure 5 shows the breakdown of theories used in CSRS research.

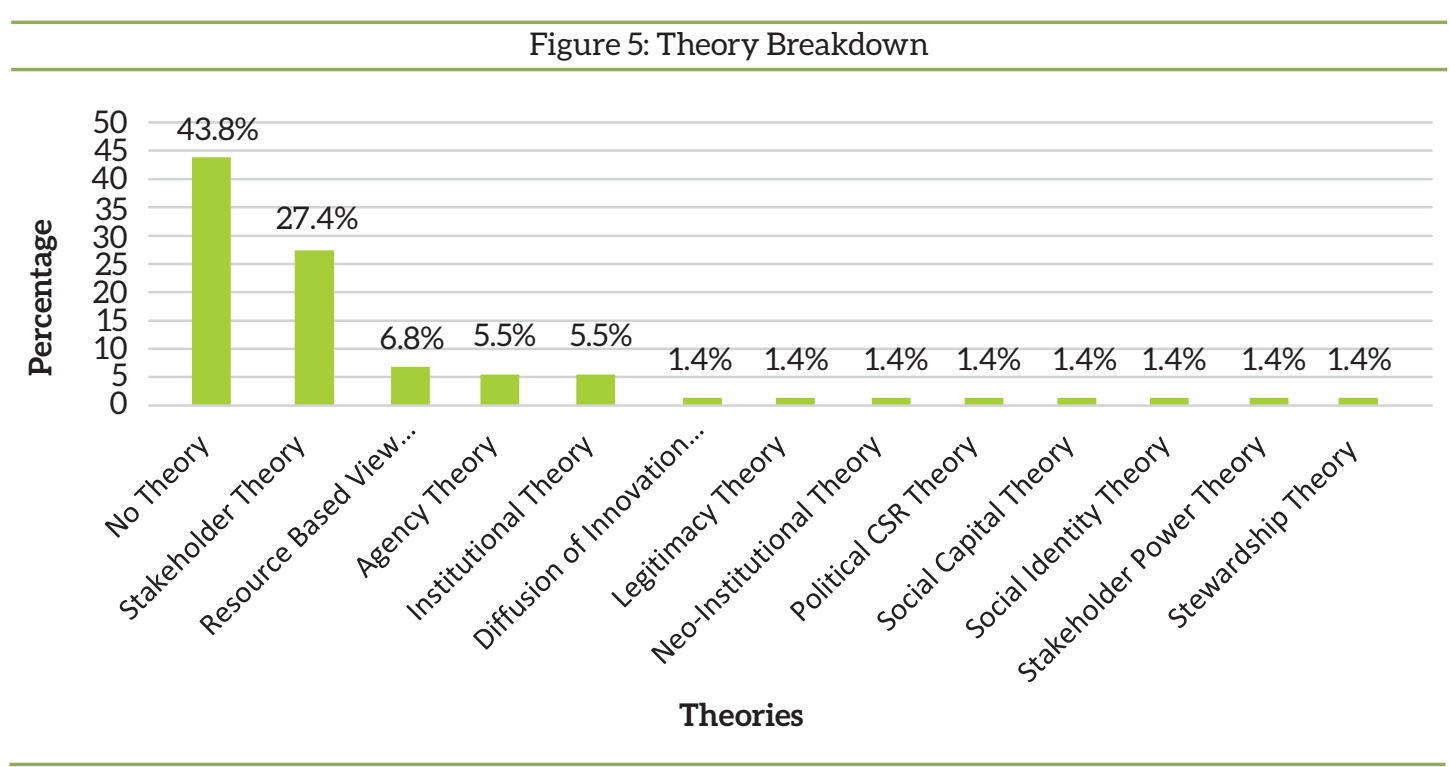

Source: Authors' review

The breakdown revealed that 12 theories were utilized. However, a significant number of papers did not adopt any theory in their analysis (43.8 percent). The top four theories applied in CSRS research are Stakeholder Theory (27.4 percent), Resource Based View Theory (6.8 percent), Agency and Institutional theories (5.5 percent respectively). The stakeholder theory provides insights on how SMEs manage their multiple stakeholders (Agyemang \& Ansong, 2017; Jain et al., 2017; Park et al., 2017). Resource based view theory is used to identify the resources and capabilities generated by SMEs as a result of CSR implementation, these resources bring about 
sustainable competitive advantage (Amaeshi et al., 2016; Stoian \& Gilman, 2016; MartínezMartínez et al., 2017). Agency Theory provided the bases for analysing the relationship between profit maximization for SME owners and CSR implementation (El Baz et al., 2016; Agyemang \& Ansong, 2017; Mtar, 2019). Institutional theory aided the identification of rules, believes and norms that are concerned with CSR implementation in SMEs (Lund-Thomsen et al., 2014; Lee et al., 2017; O'Connor et al., 2017).

A lot of the articles analysed did not adopt any theory, and this further reiterates the need for the publication of more CSRS conceptual articles. Conceptual articles provide theoretical discussions, which sometimes brings about the emergence of theories. Theories provide guidance for empirical research (Patten \& Newhart, 2017).

\subsection{CSRS Research Themes}

Analysis of the 62 CSRS articles reveals that four CSRS themes were explored; Figure 6 reflects these themes.

Figure 6. CSRS Research Themes

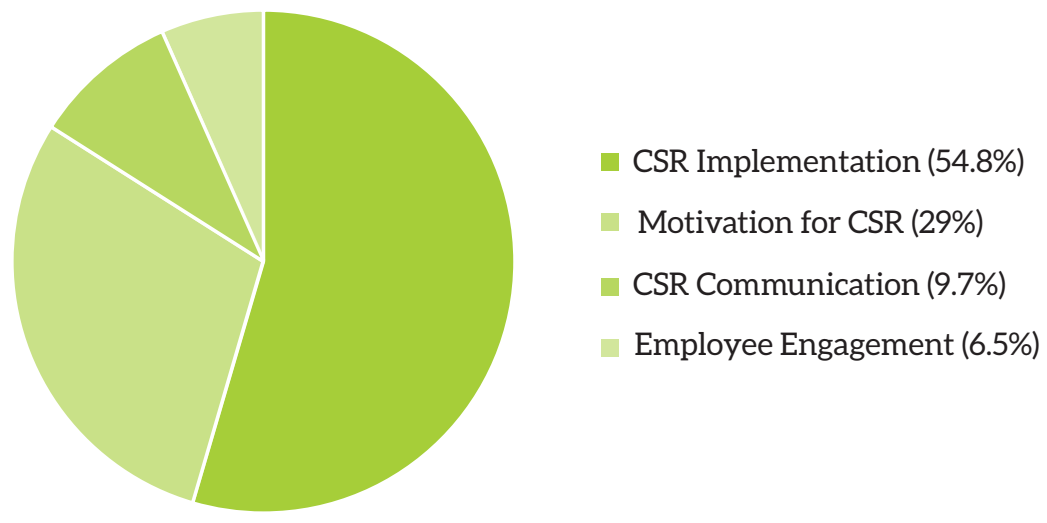

Source: Authors' review

More than half of the articles reviewed (54.8\%) addressed CSR implementation. These studies identified that a large number of SMEs do not implement CSR due to resource constraints and lack of proper education on the benefits of CSR (c.f. Fen Tseng et al., 2010; Indarti \& Efni, 2018; Zoysa \& Takaoka, 2019). Also, the few SMEs implementing CSR mostly utilized external oriented informal approaches (c.f. Bevan and Yung, 2015; Jain et al., 2016; Raza \& Majid, 2016). Implementing CSR is beneficial to SMEs, as it can lead to efficient utilization of resources and serve as a marketing tool (c.f. Vancheswaran \& Gautam, 2011; Robertson, 2017; Mtar, 2019). However, for an SME to derive benefits from its CSR implementation, it must be in line with the company's strategy; this means that CSR activities should be planned in line with the business core objectives (c.f. Santos, 2011; Tamajon \& Font, 2013; Graafland, 2018). Work force and community related CSR were suggested as some ideal CSR activities for SMEs (Gorondutse \& Hillman, 2016; Stoian \& Gilman, 2016; Agyemang \& Ansong, 2017).

The above findings revealed by CSR implementation themed papers, identifies the need for more SMEs to participate in CSR. However, this should not be done in a generic way, CSR implementation should involve proper planning and education. This will ensure that the implementation brings about opportunity creation and competitive advantage for the SME. For instance, the case of Wecyclers discussed in the introduction, shows how CSR implementation can create a business opportunity. Wecyclers is a recycling company that helps residents collect waste, as part of its CSR activities. Some of the waste collected is useful to the company's recycling business. 
Resource constraints is one of the reasons for SMEs non-participation in CSR. Financial sector regulators in various countries (Central Banks), can help improve SMEs funding status by making policies that ensure interest rates are favourable. Favourable interest rates will encourage SMEs to access funds through loans. These funds although for business will also contribute to CSR, as a result of SMEs carrying out business operations in more efficient ways. E.g. a restaurant that previously cooked with fire wood, thus contributing to pollution, will afford to buy a gas cooker because it has access to more money.

The second most common theme among CSRS research is motivation for participation (29\%). These articles identified some factors that motivate SMEs to participate in CSR. The factors identified included legislation, values of business owners and managers, relevance of stakeholders' engagement and pursuit for profitability (c.f. Lee et al., 2016; Tang \& Tang, 2017; Dey et al., 2018). Although not common, external donors may sometimes motivate SMEs to participate in CSR (Coppa \& Sriramesh, 2013). Socially responsible SMEs also encourage other companies to participate in CSR, this is because they restrict their business activities to only socially responsible companies (Biong \& Silkoset, 2017).

Based on the above findings it can be observed that CSR has the prospect of making a business profitable, hence SME owners need to take part in CSR to achieve business profitability. It has also been identified that SMEs can be motivators for other businesses to take part in CSR. SMEs can do this by restricting their choice of business partners based on social responsibility. Businesses will be motivated to participate in CSR because of the business opportunity attached to being a socially responsible company, and this will ensure better achievement of sustainable development.

Legislation has been identified as a motivation for CSR implementation in SMEs. Policy makers need to make more CSR laws, so as to enhance better participation. For instance, in Nigeria CSR laws is focused on taxation, businesses are not held accountable on other measures. A CSR bill is currently being considered in the country's National Assembly. This bill is proposing other CSR standards and also the establishment of a supervisory body to monitor CSR activities. A CSR focused bill and supervisory organization should exist in all countries. To further increase SMEs CSR participation, a bill and law focused on CSRS can be constituted.

The third most common theme among CSRS research was CSR communication (9.7\%). These articles revealed that CSR communication among SMEs is low (Dincer \& Dincer, 2010; Parker et al., 2015; O'Connor et al., 2017). The reasons for the low level of CSR communication were revealed as: fear of criticism, lack of proper management skills and resources (Dincer \& Dincer, 2010). Some studies identified the channels through which CSR can be communicated; these channels were classified as formal and informal. Word of mouth from employees, customers and third party endorsement constitute informal CSR communication channels (Lee-Wong \& More, 2016). On the other hand, CSR reports and websites of companies constitute formal CSR communication channels (Dincer \& Dincer, 2010; Lee-Wong \& More, 2016).

More SMEs need to communicate their CSR activities in other to improve their corporate image and competitiveness. However, to avoid criticism and miscommunication only verifiable claims should be made. The low level of CSR communication among SMEs identifies that they are not held accountable for their social responsibility. Mandatory CSR reporting laws only focus on large companies (Edwards, 2018). Parliaments of various countries need to include SMEs under the mandatory CSR reporting law. However, a different reporting standard should be set for them because their operation scale differs from that of large companies. This will encourage CSR communication and also implementation among SMEs

The last theme identified in CSRS research was employee engagement (6.5\%). These articles revealed that internal stakeholders which comprise of employees are neglected in CSR initiatives; this is because the CSR activities implemented by SMEs are not employee focused (Davies \& Crane, 2010; Johan de Jong, 2011). Also, SME owners often do not consult employees 
before making decisions on external CSR implementation, this is not an ideal practice; although business owners and managers initiate CSR implementation, employees are the drivers of the process (Davies \& Crane, 2016; Sendlhofer, 2019).

Employee focused CSR is a recent trending and relevant aspect of CSR among large companies (Sharma \& Gupta, 2019). SMEs need to involve their employees more in their CSR activities, so as to take advantage of this current CSR trend. This will be beneficial to them as employee morale will be boosted, and also new talents can be attracted to the company. A survey showed that prospective employees consider CSR implementation as a criterion when choosing companies to work for (Waithe, 2018).

\subsection{Research Methods}

Figure 7 presents a summary of the research methods utilized in CSRS research. Analysis of the 62 CSRS articles identified six primary research methods used.

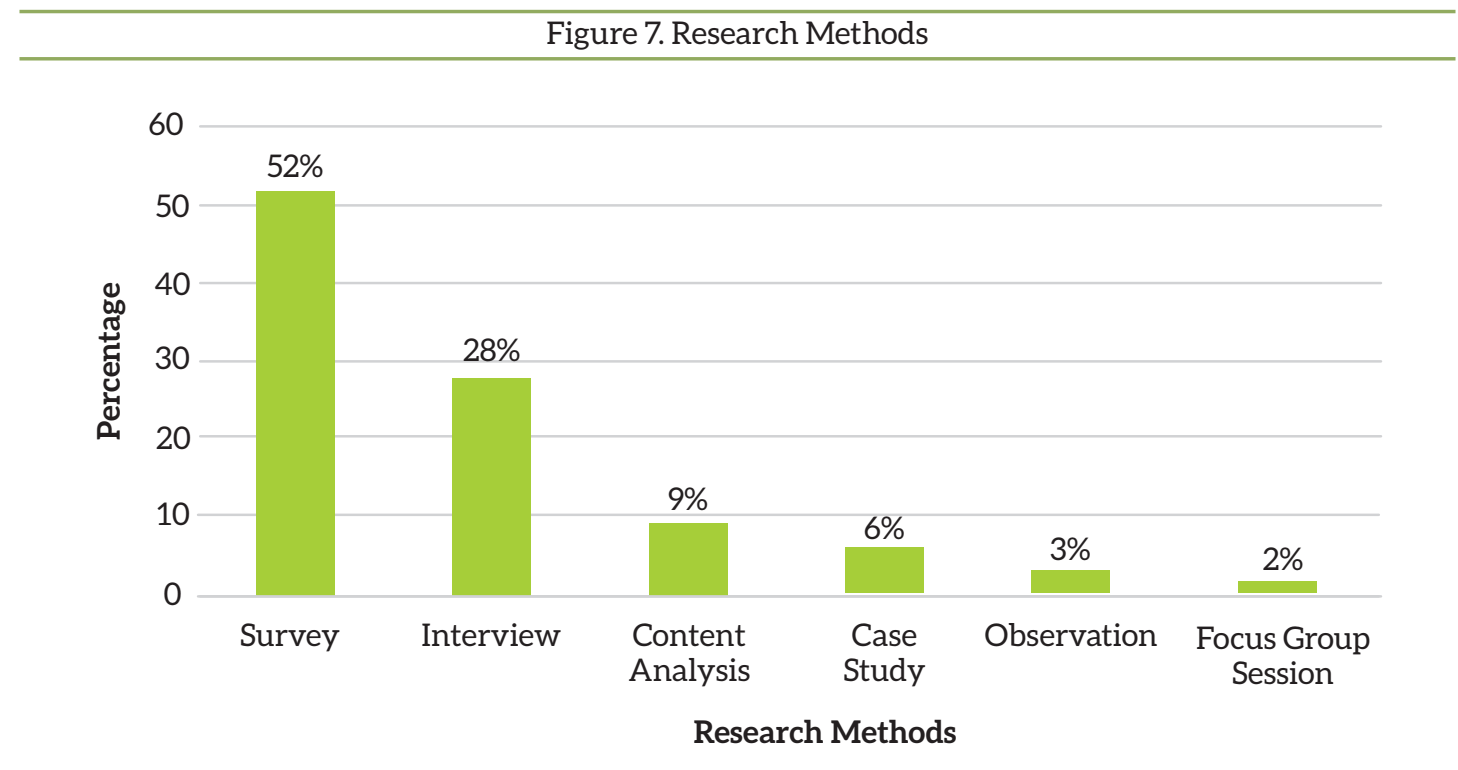

Source: Authors' review

More than half of the studies reviewed (52\%) used surveys (c.f. Agyemang \& Ansong, 2017; Biong \& Silkoset, 2017; Graffland, 2018) as their primary research method. This was followed by interview of various SMEs stakeholders (28\%) (c.f. Dincer \& Dincer, 2013; McCaffrey \& Kurland, 2015; Lee-Wong \& More, 2016) and Content analysis (9\%) (c.f. Dincer \& Dincer, 2010; O'Connor et al., 2017; Indarti \& Efni, 2018). The other three research methods were utilized in less than 5 articles. Four articles, representing $6 \%$ of articles reviewed, adopted case study method in their analysis (Von Weltzien Hoivik, 2011; Del Baldo, 2012; Amaeshi et al., 2016; Sendlhofer, 2019). Two articles Davies and Crane (2010) and Lund-Thomsen et al. (2014), both used observation in their analysis. The use of focus group session was employed by Amaeshi et al. (2016).

Majority of CSRS research used survey. This method is not devoid of limitations. Blasius and Thiessen (2012) states that survey may sometimes not present the true picture of a situation; this is because of omission of cases that should have been included in the survey. Future studies should explore the use of other methods. An opportunity also exists for researchers to adopt a combination of methods. It is observed that most of the papers reviewed adopted a single research method. In other to have several perspectives and to ensure a high level of accuracy, future CSRS research can combine two or more research methods. 


\section{Conclusion}

This paper reviewed 62 peer-reviewed journal articles on CSR in SMEs context (CSRS). These articles were examined along six key categories, including the time distribution of the articles, geographical distribution of the article, article type, theories used, research themes and research methods. The results of the review were discussed and directions for future research were provided. Although a reasonable number of CSRS studies have been conducted, there is still significant room for more conceptual research in this area, particularly considering the important contribution of SMEs CSR implementation to the achievement of global sustainable development.

Some limitations exist in this study; these limitations are gaps future CSRS research can explore. The first limitation is that this study is time bound, only articles published in 2010 and later years were used. Future research may include earlier years, as this may provide some useful insight.

The second limitation is that this study used title search in six databases. Although, these databases contain high quality, peer-reviewed articles, they definitely do not contain all peerreviewed CSRS articles. Future systematic reviews can widen the scope of databases to gain further insight in CSRS research.

Another limitation is that only English journal articles were included in the review; book chapters and conference proceedings were excluded. This was done in accordance with the SQAT methodology to maintain the high quality of articles reviewed. However, there is potentially very useful insight in book chapters and conference proceedings, which future research would do well to include.

A further limitation is the fact that a title word search was utilized rather than a key word search. A title word search provides a more precise search of articles that are dealing with CSRS. However, a key word search would have produced a greater number of articles for the review. Some of the papers might not have been directly addressing CSRS, but might have provided useful insight.

Notwithstanding, these limitations, this study is important as it provides a clear picture on the current state of CSRS research and gives a clear direction on the areas that future research needs to address in order to ensure CSR is properly implemented by SMEs, in ways that will be beneficial to the business and the environment at large. 


\section{References}

Agyemang, O. S., \& Ansong, A. (2017). Corporate social responsibility and firm performance of Ghanaian SMEs. Journal of Global Responsibility, 8(1), 47-62. https://doi.org/10.1108/JGR-03-2016-0007

Akinpelu, O. (2019). Recycling Startup, Wecyclers to Get N81.4 Million After Winning King Baudouin Foundation's African Development Prize. Retrieved March 25, 2019, from https://technext. ng/2019/03/25/recycling-startup-wecyclers-get-n81-4-million-winning-king-baudouin-foundationsafrican-development-prize/

Al-Tit, A., Omri, A., \& Euchi, J. (2019). Critical Success Factors of Small and Medium-Sized Enterprises in Saudi Arabia: Insights from Sustainability Perspective. Administrative Sciences, 9(2), 32. https://doi. org/10.3390/admsci9020032

Amaeshi, K., Adegbite, E., Ogbechie, C., Idemudia, U., Kan, K. A. S., Issa, M., \& Anakwue, O. I. J. (2016). Corporate Social Responsibility in SMEs: A Shift from Philanthropy to Institutional Works? Journal of Business Ethics, 138(2), 385-400. https://doi.org/10.1007/s10551-015-2633-1

Annor-Esteban, V., García-Sánchez, I.-M., \& Galindo-Villardón, M.-P. (2018). Analysing the Effect of Legal System on Corporate Social Responsibility (CSR) at the Country Level, from a Multivariate Perspective. Social Indicators Research, 140(1), 435-452. https://doi.org/10.1007/s11205-017-1782-2

Annor, I. (2019). Climate Action: Lagos-based "Wecyclers" wins African Development Prize. Retrieved March 23, 2019, from https://www.africanews.com/2019/03/22/climate-action-lagos-based-wecyclers-winsafrican-development-prize-201819/

Bevan, E. A. M., \& Yung, P. (2015). Implementation of corporate social responsibility in Australian construction SMEs. Engineering, Construction and Architectural Management, 22(3), 295-311. https:// doi.org/10.1108/ECAM-05-2014-0071

Biong, H., \& Silkoset, R. (2017). Buying CSR with employees' pensions? The effect of social responsible investments on Norwegian SMEs' choice of pension fund management. International Journal of Bank Marketing, 35(1), 56-74. https://doi.org/10.1108/IJBM-10-2015-0162

Blasius, J., \& Thiessen, V. (2012). Assessing the Quality of Survey Data. London, UK: SAGE Publications Ltd. https://doi.org/10.4135/9781446251874

Caputo, R. K. (2019). Peer Review: A Vital Gatekeeping Function and Obligation of Professional Scholarly Practice. Families in Society: The Journal of Contemporary Social Services, 100(1), 6-16. https://doi. org/10.1177/1044389418808155

Carley, M., \& Christie, I. (2017). Managing sustainable development. London, UK: Routledge. https://doi. org/10.4324/9781315091525

Col, B., \& Patel, S. (2019). Going to Haven? Corporate Social Responsibility and Tax Avoidance. Journal of Business Ethics, 154(4), 1033-1050. https://doi.org/10.1007/s10551-016-3393-2

Coppa, M., \& Sriramesh, K. (2013). Corporate social responsibility among SMEs in Italy. Public Relations Review, 39(1), 30-39. https://doi.org/10.1016/j.pubrev.2012.09.009

Davies, I. A., \& Crane, A. (2010). Corporate social responsibility in small-and medium-size enterprises: investigating employee engagement in fair trade companies. Business Ethics: A European Review, 19(2), 126-139. https://doi.org/10.1111/j.1467-8608.2010.01586.x 
Del Baldo, M. (2012). Corporate social responsibility and corporate governance in Italian SMEs: the experience of some "spirited businesses." Journal of Management \& Governance, 16(1), 1-36. https://doi. org/10.1007/s10997-009-9127-4

Demuijnck, G., \& Ngnodjom, H. (2013). Responsibility and Informal CSR in Formal Cameroonian SMEs. Journal of Business Ethics, 112(4), 653-665. https://doi.org/10.1007/s10551-012-1564-3

Dey, P. K., Petridis, N. E., Petridis, K., Malesios, C., Nixon, J. D., \& Ghosh, S. K. (2018). Environmental management and corporate social responsibility practices of small and medium-sized enterprises. Journal of Cleaner Production, 195, 687-702. https://doi.org/10.1016/j.jclepro.2018.05.201

Dincer, B., \& Dincer, C. (2013). Corporate social responsibility decisions: a dilemma for SME executives? Social Responsibility Journal, 9(2), 177-187. https://doi.org/10.1108/SRJ-07-2011-0028

Dincer, C., \& Dincer, B. (2010). An investigation of Turkish small and medium-sized enterprises online CSR communication. Social Responsibility Journal, 6(2), 197-207. https://doi.org/10.1108/17471111011051711

Doshmanli, M., Salamzadeh, Y., \& Salamzadeh, A. (2018). Development of SMEs in an emerging economy: does corporate social responsibility matter? International Journal of Management and Enterprise Development, 17(2), 168. https://doi.org/10.1504/IJMED.2018.090827

Dubruc, N., Mekdessi, S., \& Khawaja, D. (2018). Towards an eventual three-dimensional equilibrium regarding corporate social responsibility in Lebanese small and medium enterprises. World Review of Entrepreneurship, Management and Sustainable Development, 14(1/2), 229. https://doi.org/10.1504/ WREMSD.2018.089069

Edgell, S. (2018). CSR and the art of securing loyalty. Retrieved from http://www.smeweb.com/2019/04/11/ csr-art-securing-loyalty/

Edwards, C. (2018). Your Small Business Needs a Corporate Social Responsibility Report. Retrieved June 15, 2018, from https://www.businessnewsdaily.com/10909-corporate-social-responsibility-reportingsmall-business.html

El Baz, J., Laguir, I., Marais, M., \& Staglianò, R. (2016). Influence of National Institutions on the Corporate Social Responsibility Practices of Small- and Medium-sized Enterprises in the Food-processing Industry: Differences Between France and Morocco. Journal of Business Ethics, 134(1), 117-133. https:// doi.org/10.1007/s10551-014-2417-z

Fen Tseng, Y., Jim Wu, Y., Wu, W., \& Chen, C. (2010). Exploring corporate social responsibility education. Management Decision, 48(10), 1514-1528. https://doi.org/10.1108/00251741011090306

Gorondutse, A.H., \& Hilman, H. (2016). The moderating effect of organisational culture on the commitment to corporate social responsibility (CSR) and the performance of SMEs in Nigeria. Journal of General Management, 42(1), 65-77. https://doi.org/10.1177/030630701604200105

Graafland, J. (2018). Does Corporate Social Responsibility Put Reputation at Risk by Inviting Activist Targeting? An Empirical Test among European SMEs. Corporate Social Responsibility and Environmental Management, 25(1), 1-13. https://doi.org/10.1002/csr.1422

Gupta, S., Sukhmani, \& Kalra, N. (2012). Impact of Corporate Social Responsibility on SMEs in India. Asia-Pacific Journal of Management Research and Innovation, 8(2), 133-143. https://doi. org/10.1177/2319510X1200800206 
Indarti, S., \& Efni, Y. (2018). Comparative study. International Journal of Law and Management, 60(2), 311324. https://doi.org/10.1108/IJLMA-12-2016-0160

Jain, P., Vyas, V., \& Chalasani, D. P. S. (2016). Corporate Social Responsibility and Financial Performance in SMEs: A Structural Equation Modelling Approach. Global Business Review, 17(3), 630-653. https://doi. org/10.1177/0972150916630827

Jain, P., Vyas, V., \& Roy, A. (2017). Exploring the mediating role of intellectual capital and competitive advantage on the relation between CSR and financial performance in SMEs. Social Responsibility Journal, 13(1), 1-23. https://doi.org/10.1108/SRJ-04-2015-0048

Jamali, D., \& Karam, C. (2018). Corporate Social Responsibility in Developing Countries as an Emerging Field of Study. International Journal of Management Reviews, 20(1), 32-61. https://doi.org/10.1111/ ijmr.12112

Jamali, D., Lund-Thomsen, P., \& Jeppesen, S. (2017). SMEs and CSR in Developing Countries. Business \& Society, 56(1), 11-22. https://doi.org/10.1177/0007650315571258

Jansson, J., Nilsson, J., Modig, F., \& Hed Vall, G. (2017). Commitment to Sustainability in Small and MediumSized Enterprises: The Influence of Strategic Orientations and Management Values. Business Strategy and the Environment, 26(1), 69-83. https://doi.org/10.1002/bse.1901

Johan de Jong, D. (2011). International transfer of employee-oriented CSR practices by multinational SMEs. International Journal of Workplace Health Management, 4(2), 123-139. https://doi. org/10.1108/17538351111143303

Kucharska, W., \& Kowalczyk, R. (2019). How to achieve sustainability?-Employee's point of view on company's culture and CSR practice. Corporate Social Responsibility and Environmental Management, 26(2), 453-467. https://doi.org/10.1002/csr.1696

Lee, H.-Y., Kwak, D.-W., \& Park, J.-Y. (2017). Corporate Social Responsibility in Supply Chains of Small and Medium-Sized Enterprises. Corporate Social Responsibility and Environmental Management, 24(6), 634647. https://doi.org/10.1002/csr.1433

Lee, K.-H., Herold, D. M., \& Yu, A.-L. (2016). Small and Medium Enterprises and Corporate Social Responsibility Practice: A Swedish Perspective. Corporate Social Responsibility and Environmental Management, 23(2), 88-99. https://doi.org/10.1002/csr.1366

Lee, M. H., Mak, A. K., \& Pang, A. (2012). Bridging the Gap: An Exploratory Study of Corporate Social Responsibility among SMEs in Singapore. Journal of Public Relations Research, 24(4), 299-317. https:// doi.org/10.1080/1062726X.2012.689898

Lee-Wong, B. Y., \& More, E. (2016). Management of corporate social responsibility in Hong Kong small and medium enterprises. Journal of Global Responsibility, 7(2), 146-162. https://doi.org/10.1108/JGR-072016-0018

López-Pérez, M. E., Melero, I., \& Javier Sese, F. (2017). Management for Sustainable Development and Its Impact on Firm Value in the SME Context: Does Size Matter? Business Strategy and the Environment, 26(7), 985-999. https://doi.org/10.1002/bse.1961

Lucky, E. O. I. (2018). An empirical examination of the influence of corporate social responsibility dimensions on the small and medium enterprise performance in Northern Malaysia. International Journal of Business Innovation and Research, 16(2), 243. https://doi.org/10.1504/IJBIR.2018.091919 
Lund-Thomsen, P., Jamali, D., \& Vives, A. (2014). CSR in SMEs: an analysis of donor-financed management tools. Social Responsibility Journal, 10(4), 602-619. https://doi.org/10.1108/SRJ-02-2013-0012

Maas, K., \& Boons, F. (2017). CSR as a strategic activity: Value creation, redistribution and integration. In Innovative CSR: From Risk Management to Value Creation (pp. 153-172). Greenleaf Publishing Limited. https://doi.org/10.9774/GLEAF.978-1-907643-26-2_9

Martínez-Martínez, D., Herrera Madueño, J., Larrán Jorge, M., \& Lechuga Sancho, M. P. (2017). The strategic nature of corporate social responsibility in SMEs: a multiple mediator analysis. Industrial Management \& Data Systems, 117(1), 2-31. https://doi.org/10.1108/IMDS-07-2015-0315

McCaffrey, S. J., \& Kurland, N. B. (2015). Does "Local" Mean Ethical? The U.S. "Buy Local" Movement and CSR in SMEs. Organization \& Environment, 28(3), 286-306. https://doi.org/10.1177/1086026615586795

McClimon, T. J. (2019). 5 Corporate Social Responsibility Trends For Leaders To Watch In 2019. Retrieved January 3, 2019, from https://www.forbes.com/sites/timothyjmcclimon/2019/01/03/5-corporatesocial-responsibility-csr-trends-for-leaders-to-watch-in-2019/\#3f5af5f5553d

Melissen, F., Mzembe, A. N., Idemudia, U., \& Novakovic, Y. (2018). Institutional Antecedents of the Corporate Social Responsibility Narrative in the Developing World Context: Implications for Sustainable Development. Business Strategy and the Environment, 27(6), 657-676. https://doi.org/10.1002/bse.2023

Meyer, M., Narjoud, S., \& Granata, J. (2017). When collective action drives corporate social responsibility implementation in small and medium-sized enterprises: the case of a network of French winemaking cooperatives. International Journal of Entrepreneurship and Small Business, 32(1/2), 7. https://doi. org/10.1504/IJESB.2017.086002

Moneva, J. M., \& Pajares, J. H. (2018). Corporate social responsibility performance and sustainability reporting in SMEs: an analysis of owner-managers' perceptions. International Journal of Sustainable Economy, 10(4), 405. https://doi.org/10.1504/IJSE.2018.095268

Mtar, K. (2019). CSR discourse: A factor affecting the success of France's SMEs? Quality Management Journal, 26(2), 84-99. https://doi.org/10.1080/10686967.2019.1580120

O'Connor, A., Parcha, J. M., \& Tulibaski, K. L. G. (2017). The Institutionalization of Corporate Social Responsibility Communication: An Intra-Industry Comparison of MNCs' and SMEs' CSR Reports. Management Communication Quarterly, 31(4), 503-532. https://doi.org/10.1177/0893318917704512

Oluwole, V. (2019). Nigerian Startup, Wecyclers wins $€ 200,000$ prize for waste management. Retrieved from https://businesselitesafrica.com/trending/wecyclers-wins-prize-waste-management/

Organization for Economic Cooperation and Development - OECD (2017). Enhancing the contributions of SMEs in a global and digitalized economy. Meeting of the OECD Council at Ministerial Level. Retrieved from https://www.oecd.org/mcm/documents/C-MIN-2017-8-EN.pdf

Ortiz-Avram, D., Domnanovich, J., Kronenberg, C., \& Scholz, M. (2018). Exploring the integration of corporate social responsibility into the strategies of small- and medium-sized enterprises: A systematic literature review. Journal of Cleaner Production, 201, 254-271. https://doi.org/10.1016/j. jclepro.2018.08.011

Panwar, R., Nybakk, E., Hansen, E., \& Pinkse, J. (2017). Does the Business Case Matter? The Effect of a Perceived Business Case on Small Firms' Social Engagement. Journal of Business Ethics, 144(3), 597608. https://doi.org/10.1007/s10551-015-2835-6 
Park, Y., Park, Y., Hong, P. C., \& Yang, S. (2017). Clarity of CSR orientation and firm performance: case of Japanese SMEs. Benchmarking: An International Journal, 24(6), 1581-1596. https://doi.org/10.1108/BIJ03-2016-0035

Parker, C. M., Bellucci, E., Zutshi, A., Torlina, L., \& Fraunholz, B. (2015). SME stakeholder relationship descriptions in website CSR communications. Social Responsibility Journal, 11(2), 364-386. https://doi. org/10.1108/SRJ-09-2013-0114

Patten, M. L., \& Newhart, M. (2017). Understanding research methods: An overview of the essentials (Tenth edit). New York, USA: Routledge

Pickering, C., \& Byrne, J. (2014). The benefits of publishing systematic quantitative literature reviews for $\mathrm{PhD}$ candidates and other early-career researchers. Higher Education Research \& Development, 33(3), 534-548. https://doi.org/10.1080/07294360.2013.841651

Rahim, M. M., \& Wisuttisak, P. (2013). Corporate Social Responsibility-Oriented Compliances and SMEs Access to Global Market: Evidence from Bangladesh. Journal of Asia-Pacific Business, 14(1), 58-83. https://doi.org/10.1080/10599231.2013.741417

Ray, J. S. (2018). 10 Facts About Poverty in South America. Retrieved June 28, 2018, from https:// borgenproject.org/facts-about-poverty-in-south-america/

Raza, J., \& Majid, A. (2016). Perceptions and practices of corporate social responsibility among SMEs in Pakistan. Quality \& Quantity, 50(6), 2625-2650. https://doi.org/10.1007/s11135-015-0281-2

Robertson, J. A. (2017). Boosting Ghanaian SME performance. Annals in Social Responsibility, 3(1), 72-74. https://doi.org/10.1108/ASR-10-2017-0012

Rothenberg, S., Hull, C. E., \& Tang, Z. (2017). The Impact of Human Resource Management on Corporate Social Performance Strengths and Concerns. Business \& Society, 56(3), 391-418. https://doi. org/10.1177/0007650315586594

Santos, M. (2011). CSR in SMEs: strategies, practices, motivations and obstacles. Social Responsibility Journal, 7(3), 490-508. https://doi.org/10.1108/17471111111154581

Schmidt, F., Zanini, R., Korzenowski, A., Schmidt Junior, R., \& Xavier do Nascimento, K. (2018). Evaluation of sustainability practices in small and medium-sized manufacturing enterprises in Southern Brazil. Sustainability, 10(7), 2460. https://doi.org/10.3390/su10072460

Sendlhofer, T. (2019). Decoupling from Moral Responsibility for CSR:Employees' Visionary Procrastination at a SME. Journal of Business Ethics. https://doi.org/10.1007/s10551-019-04174-z

Sharma, J., \& Gupta, S. (2019). 5 Trends That Will Redefine The CSR Sector in 2019. Retrieved February 7, 2019, from https://www.entrepreneur.com/article/327657

Sidalak, D., Purdy, E., Luckett-Gatopoulos, S., Murray, H., Thoma, B., \& Chan, T. M. (2017). Coached Peer Review. Academic Medicine, 92(2), 201-204. https://doi.org/10.1097/ACM.0000000000001224

Stafford-Smith, M., Griggs, D., Gaffney, O., Ullah, F., Reyers, B., Kanie, N., O'Connell, D. et al. (2017). Integration: the key to implementing the Sustainable Development Goals. Sustainability Science, 12(6), 911-919. https://doi.org/10.1007/s11625-016-0383-3

Stoian, C., \& Gilman, M. (2017). Corporate Social Responsibility That "Pays": A Strategic Approach to CSR for SMEs. Journal of Small Business Management, 55(1), 5-31. https://doi.org/10.1111/jsbm.12224 
Sustainia. (2018). Providing Incentives for Recycling in Low-Income Communities. Retrieved June 25, 2018, from https://goexplorer.org/providing-incentives-for-recycling-in-low-income-communities/

Takalandze, L., \& Mohammad, R. N. (2019). Implementing corporate social responsibility as a dynamic capability in recent modern agri-business SMES' concerns. Fundamental and Applied Researches in Practice of Leading Scientific Schools, 31(1), 217-219. https://doi.org/10.33531/farplss.2019.1.41

Tamajón, L. G., \& Font, X. (2013). Corporate social responsibility in tourism small and medium enterprises evidence from Europe and Latin America. Tourism Management Perspectives, 7, 38-46. https://doi. org/10.1016/j.tmp.2013.03.002

Tang, Z., \& Tang, J. (2012). Stakeholder-firm power difference, stakeholders' CSR orientation, and SMEs' environmental performance in China. Journal of Business Venturing, 27(4), 436-455. https://doi. org/10.1016/j.jbusvent.2011.11.007

Tang, Z., \& Tang, J. (2018). Stakeholder Corporate Social Responsibility Orientation Congruence, Entrepreneurial Orientation and Environmental Performance of Chinese Small and Medium-sized Enterprises. British Journal of Management, 29(4), 634-651. https://doi.org/10.1111/1467-8551.12255

The Guardian. (2018). Firm donates boreholes, learning materials to Osun community. Retrieved April16, 2018, from https://guardian.ng/news/firm-donates-boreholes-learning-materials-to-osun-community/

The Tony Elemelu Foundation. (2017). Bilikiss Adebiyi-Abiola is Cascading Impact Across the Environment. Retrieved November 24, 2017, from https://www.tonyelumelufoundation.org/west-africa/bilikissadebiyi-abiola-is-cascading-impact-across-the-environment

Torugsa, N. A., O'Donohue, W., \& Hecker, R. (2012). Capabilities, Proactive CSR and Financial Performance in SMEs: Empirical Evidence from an Australian Manufacturing Industry Sector. Journal of Business Ethics, 109(4), 483-500. https://doi.org/10.1007/s10551-011-1141-1

United Nations. (2018). United Nations Environment Programme, Annual Report 2018. Retrieved from https://www.unenvironment.org/annualreport/2018/index.php\#cover

United Nations. (2019). Micro-, Small and Medium-sized Enterprises Day 27 June. Retrieved from https:// www.un.org/en/events/smallbusinessday/

Van Woerkom, P. M., \& Van Zeijl Rozema, A. (2017). Improving local implementation of an MNC's global CSR strategy: the importance of stakeholders. International Journal of Business Environment, 9(3), 247. https://doi.org/10.1504/IJBE.2017.10008888

Vancheswaran, A., \& Gautam, V. (2011). CSR in SMEs: Exploring a Marketing Correlation in Indian SMEs. Journal of Small Business \& Entrepreneurship, 24(1), 85-98. https://doi.org/10.1080/08276331.2011.1059 3527

Vázquez-Carrasco, R., \& López-Pérez, M. E. (2013). Small \& medium-sized enterprises and Corporate Social Responsibility: a systematic review of the literature. Quality \& Quantity, 47(6), 3205-3218. https://doi. org/10.1007/s11135-012-9713-4

Von Weltzien Hoivik, H. (2011). Embedding CSR as a learning and knowledge creating process: the case for SMEs in Norway. Journal of Management Development, 30(10), 1067-1084. https://doi. org/10.1108/02621711111182547

Waithe, M. (2018). The importance of CSR to small businesses, start-ups. Retrieved December 13, 2018, from https://newsday.co.tt/2018/12/13/the-importance-of-csr-to-small-businesses-start-ups/ 
World Bank. (2018). What a Waste: An Updated Look into the Future of Solid Waste Management. Retrieved from https://www.worldbank.org/en/news/immersive-story/2018/09/20/what-a-waste-an-updatedlook-into-the-future-of-solid-waste-management

World Map. (2019). How Many Countries are in the World? Retrieved from http://www.worldatlas.com/ nations.htm

World Bank. (2019). Small and Medium Enterprises (SMEs) Finance. Retrieved from https://www.worldbank. org/en/topic/smefinance

Wu, G.-C. (2017). Effects of Socially Responsible Supplier Development and Sustainability-Oriented Innovation on Sustainable Development:Empirical Evidence from SMEs. CorporateSocial Responsibility and Environmental Management, 24(6), 661-675. https://doi.org/10.1002/csr.1435

Yeo, A. C. M., \& Carter, S. (2018). Corporate Social Responsibility Intervention: A Catalyst to Small-Medium Enterprise Employee Engagement. Psychosociological Issues in Human Resource Management, 6(1), 3862. https://www.ceeol.com/search/article-detail?id=665231

Zoysa, A. De, \& Takaoka, N. (2019). Corporate social responsibility performance of small and medium enterprises in regional Japan: an empirical examination. Social Responsibility Journal. https://doi. org/10.1108/SRJ-05-2018-0116 